\title{
O CONTROLO DO CONTEÚDO DAS CLÁUSULAS CONTRATUAIS GERAIS NO CONTRATO DE SEGURO
}

\author{
CONTENT CONTROL OF THE GENERAL CONTRACTUAL CLAUSES IN THE \\ INSURANCE CONTRACT
}

\author{
Maria Inês Viana de Oliveira Martins \\ Mestre e Doutora em Direito pela Universidade de Coimbra \\ Faculdade de Direito da Universidade de Coimbra (FDUC/Portugal) \\ Coimbra, Portugal \\ mi.oliveiramartins@gmail.com
}

\begin{abstract}
Sumário: O presente artigo debruça-se sobre as questões do controlo de conteúdo das cláusulas contratuais usadas em contratos de seguro. Em particular, aprecia-se a extensão do objecto do controlo, considerando que estão a ele sujeitas as cláusulas que interferem no recorte do risco transferido; e perspectiva-se a incidência do parâmetro de controlo material, atinente à boa fé contratual, questionando por último a pertinência de um relevo autónomo do parâmetro da transparência.

Palavras chave: Contrato de seguro; Cláusulas contratuais gerais; Controlo do conteúdo.

Contents: The present article focuses on questions regarding the control of the fairness of standard contract terms in insurance contracts. It debates which of the clauses should be subject to that control, and concludes that the clauses which shape the insured risk are subject to it. Furthermore, it specifies how the fairness standard should intervene; and, lastly, it questions whether the standard of transparency should play an autonomous role.
\end{abstract}

Keywords: Insurance contract; Standard contract terms; Fairness control.

MARTINS, Maria Inês Viana de Oliveira. O controlo do conteúdo das cláusulas contratuais gerais no contrato de seguro. Revista Thesis Juris - RTJ, São Paulo, v. 9, n. 2, p. 415-432, jul./dez. 2020.

http://doi.org/10.5585/rtj.v9i2.18683. 


\section{§ 1 Introdução. Contrato de seguro, cláusulas contratuais gerais e razões para a sindicância destas}

Os seguros assentam, em grande medida, na contratação com recurso a clausulados préelaborados e apresentados a um número indeterminado de contrapartes para adesão, sem que lhes seja possibilitada, portanto, a influência sobre o conteúdo do contrato ${ }^{1}{ }^{2}{ }^{2}$. Tendencialmente, configuram não só contratos de adesão, sendo dotados das características da pré-disposição, unilateralidade e rigidez, como contratos compostos de verdadeiras cláusulas contratuais gerais, predispostas pelo segurador para os contratos de uma determinada categoria - dotadas de generalidade - que venha a celebrar e em vista de um número indeterminado de contratantes $^{3}$. Se se lembrar que as cláusulas não deixam de ser ccg se o poder de determinação da contraparte se limita à escolha de entre uma paleta pré-definida de clausulados, predispostos para uma generalidade de negócios, ter-se-á uma noção mais clara ainda da extensão do fenómeno em sede seguradora ${ }^{4}$. Por ser através de ccg que tipicamente os contratos de seguros se exprimem enquanto contratos de adesão, reportar-nos-emos, simplesmente, àquele tipo de cláusulas 5 .

A técnica da mutualização dos riscos não é sequer pensável sem a estandardização dos clausulados a apresentar a todos os segurados que se acerquem para cobrir riscos com certas características. E, mesmo em seguros que transcendam aquela técnica ${ }^{6}$, o interesse do segurador em delimitar o risco que acolhe na sua esfera determina a pré-elaboração do conteúdo dos clausulados e a sua apresentação para mera adesão. São, claro, pensáveis hipóteses de seguros em que as cláusulas com incidência sobre o recorte do risco - inclusivamente as que consagrem exigências de conduta deste género - sejam resultado de negociação individual - pense-se nos seguros de grandes riscos que gozem de tamanha especificidade, que se torne indispensável a

\footnotetext{
${ }^{1}$ Além das abreviaturas em uso corrente, serão usados especialmente os seguintes modos de abreviar: $c c g$, cláusula(s) contratual(ais) geral(ais); Directiva, Directiva 93/13/CEE do Conselho, de 5 de Abril de 1993, relativa às cláusulas abusivas nos contratos celebrados com os consumidores; RJCCG: Regime Jurídico das Cláusulas Contratuais Gerais, aprovado pelo Decreto-Lei n. ${ }^{\circ} 446 / 85$, de 25 de Outubro; RJCS:

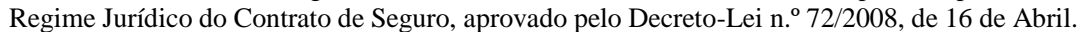

${ }^{2}$ Assim, Project Group Restatement of European InSurance ConTRACT LAw, Principles of european insurance contract law, Sellier, Munique, 2015 (no prelo; consultado em provas para publicação), p. 142 (C3), salientando exactamente que geralmente o tomador não tem possibilidade de influenciar os clausulados porque estes se encontram previamente redigidos pelo segurador. Na doutrina nacional, acentuando a articulação íntima entre oferta de serviços financeiros e contratação com recurso a ccg, JoÃo CALVÃo DA SILVA, Banca, bolsa e seguros, Direito europeu e português, Tomo I - Parte geral, Almedina, Coimbra, 2013, pp. 175-176.

${ }^{3}$ Para a distinção dos conceitos de contrato de adesão e de cláusula contratual geral e sua caracterização, ANTÓNIO PINTO MONTEIRO, "O novo regime jurídico dos contratos de adesão/ cláusulas contratuais gerais", ROA 1 (2002), ponto 3.

${ }^{4}$ Tão-pouco neste caso o aderente tem a possibilidade de influenciar a formulação ou conteúdo dos termos (PROJECT GROUP RESTATEMENT OF European Insurance Contract LAw, Principles...2015, cit., p. 143, C7); cfr. ainda, com citação da jurisprudência alemã nesse sentido, JÜRgEn PRÖlss, "I. Rechtsgrundlagen des Versicherungsvertrages", Prölss/Martin Kommentar,, CHRISTIAN ARMBRÜSTER, HeINRICH DÖRnER, DOMINIK KLIMKE, Ulrich KNAPPMANn (org.), C. H. Beck, Munique, 2010, disponível em http://beck-online.beck.de/ (22.02.2011), nm. 14 (embora o próprio autor seja crítico de tal qualificação face às hipóteses em que o segurado deva optar entre várias regras pré-formuladas).

${ }^{5}$ ANTÓNIO PINTO MONTEIRO, "O novo regime...", cit., ponto 3.

${ }^{6}$ Sobre a pluralidade das técnicas de financiamento da cobertura seguradora, permitimo-nos remeter para o nosso MARIA INÊS DE OLIVEIRA MARTINS, "Da incerteza ao risco: as técnicas seguradoras e o seu referente, num diálogo com Knight", in Estudos em Homenagem ao Doutor Avelãs Nunes, Boletim de Ciências Económicas da FDUC, II, Luís PEDRO CunHA, José MANUEL GONÇALVES SANTOS QuELHAS, TERESA AlMEIDA (org.), 2014, pp. 2174 e ss.
} 
assessoria do próprio segurado na construção da cobertura; ou no contrato pontual de cobertura de um risco celebrado por um não profissional, que ainda assim mereça a qualificação de seguro. Estas situações serão, porém, deixadas fora do foco do presente escrito, que se aterá à análise das hipóteses de utilização de ccg.

O regime de tutela face à contratação com base em ccg abrange a generalidade dos cocontratantes, independentemente de actuarem como consumidores ou empresários ou entidades equiparadas. A diferença é apenas a da intensidade da tutela em sede de controlo do conteúdo dos clausulados, beneficiando os consumidores de protecção específica face a um elenco mais alargado de cláusulas absoluta e relativamente proibidas (arts $17 .^{\circ}$ e $20 .^{\circ}$ do RJCCG).

Sendo debatida a ratio subjacente ao regime dos contratos de adesão - mais ainda, atenta a dita largueza da categoria, abarcando as cláusulas individualmente não negociadas -, é mais pacífica a atribuição de um fundamento unitário ao regime de escrutínio das verdadeiras $\operatorname{ccg}^{7}$. Este arranca de uma situação de inferioridade do aderente, que porém não se confunde com um desnível de poder económico, em concreto, de mercado, de uma parte em relação à outra ${ }^{8}$.

A fonte do desnível é identificada no próprio modus de contratar que está aqui em causa, que gera riscos específicos para o aderente. Isto encontra-se espelhado no Direito positivo, que não requer outra característica que não a contratação com recurso a clausulado estandardizado para que se aplique. Assim, entende-se que a própria utilização de ccg, "independentemente das posições de poder, globalmente consideradas, das partes em presença, inibe o aderente de defender os seus interesses, colocando-o numa posição negocial desvantajosa. Fala-se aqui de uma superioridade organizativa e "intelectual" - hoc sensu, informacional - do utilizador. Celebrando massivamente dado tipo de contratos, este tem o treino prático e, rodeando-se dos especialistas necessários, os meios para antecipar no clausulado os problemas que a execução

\footnotetext{
${ }^{7}$ Para uma contraposição, na doutrina recente, dos dois fundamentos mais comummente apontados ao regime dos contratos de adesão - a saber, o da inferioridade económica, social, intelectual ou psicológica do aderente e o da ocorrência de uma falha de mercado, derivada de um desnível informativo e motivacional do aderente -, cfr. JÜRGEN BASEDOW, "Vorbemerkung", MüKo BGB, II, Schuldrecht, Allgemeiner Teil, $\$ \$ 241$-432, WOLFGANG KRÜGER (org.), Beck, Munique, 2015, disponível em http://beck-online.beck.de (15.06.2016), nm. 4 e 5, seguido de perto, na explanação daqueles, por PHILliP HELLWEGE, "Die \$§ 307-309 enthalten zwei Formen der Inhaltskontrolle", JZ 70 (2015), pp. 1132-1133. Este último autor propõe, aliás, a atribuição distributiva destes fundamentos na compreensão do regime alemão de sindicância de cláusulas subtraídas à negociação individual: enquanto que a ocorrência de falha de mercado explicaria o regime do conjunto restrito atinente às ccg ("AGB"), que em texto contemplamos, já o regime das cláusulas unilateralmente predispostas ("EGB") se explicaria através do princípio da protecção da parte mais fraca (cfr. pp. 1134 e ss.).

${ }^{8}$ Além da doutrina citada na nota anterior, cfr. JOAQUIM DE SOUSA RIBEIRO, O problema do contrato, As cláusulas contratuais gerais e o princípio da liberdade contratual, Almedina, Coimbra, 1999, esp. pp. 330 e ss., e bibliografia aí citada. Com efeito, não se impõe como pressuposto de acesso ao regime qualquer averiguação de tal desnível - que, aliás, sempre seria problemática, dado o carácter difuso do juízo sobre o poder económico relativo. De resto, num sistema fundado na propriedade privada, toma-se como ponto de partida na interacção em mercado que os sujeitos arranquem de diferentes patamares de património e rendimento e, por isso, desde logo de diferentes posições relativas. Trata-se de um dado transversal a toda a contratação e não específico da que se processa com recurso a cláusulas contratuais gerais - dado esse que não justificaria, pois, a autonomização de um regime jurídico em torno delas (p. 337: "[a]o nivelar, sob a veste formal de partes contratantes, sujeitos cuja situação material, do ponto de vista económico, não é, em princípio, considerada, o mecanismo contratual permite, ocultando a sua natureza, que relações de poder e de supremacia se manifestem juridicamente como relações paritárias, abertas, por isso mesmo, à autonormação dos intervenientes"). Para uma aproximação do regime do controlo das ccg a um controlo massificado da usura, PEDRO PAIS DE VASCONCElos, "Cláusulas iníquas ou abusivas no contrato de seguro", in Congresso luso-hispano de Direito dos seguros, Almedina, Coimbra, 2009, p. 166; para uma panorâmica da doutrina nacional sobre a temática dos contratos de adesão, MigUEL NuNO PEDROSA MACHADO, "Sobre cláusulas contratuais gerais e conceito de risco", RFDUL (1988), pp. 98 e ss.
} 
contratual poderá colocar e dar-lhes a resposta mais satisfatória. A doutrina convoca também factores de ordem psicológica gerados por essa pré-formulação "dos termos inegociáveis em que o estipulante está disposto a contratar", que leva aliás a que tais cláusulas se aparentem, pelo seu aspecto e redacção geral e abstracta, a um sistema de normas legais: esta "gera no espírito da contraparte uma ideia de completude e imodificabilidade, que o desincentiva a tomar consciência crítica do seu conteúdo" ${ }^{9}$. Ainda quando o consumidor atipicamente tome dele conhecimento, prevalecerá "um sentimento de resignação e impotência", que o inibe de procurar a modificação de cláusulas que entenda desfavoráveis ou de recusar a contratação.

Resta dizer porque merece tal passividade do aderente tutela jurídica, não se lhe impondo que arque com as respectivas consequências. Trata-se aqui da questão da inexigibilidade ao aderente de uma conduta de tutela activa dos seus interesses, que pudesse em última linha implicar mesmo uma recusa em contratar ${ }^{10}$. Nem numa concepção da liberdade contratual que a reduza a uma mera liberdade de escolha entre alternativas oferecidas à contratação $o^{11}$, logra ela estar presente em face à contratação com uso de ccg, face à assimetria informativa que estas criam. A determinação do alcance jurídico-económico destas cláusulas implica custos desproporcionados, face aos benefícios potenciais associados, pelo que permanece uma falha de informação, que impede que o mercado funcione eficientemente, já que os adquirentes não logram comparar entre si as várias ofertas. Isto não ocorre, prima facie,

\footnotetext{
${ }^{9}$ JOAQUIM DE SOUSA RIBEIRO, O problema... cit., pp. 345-347; este desinteresse racional por parte do aderente, atentos os desrazoáveis custos de transacção que este enfrenta, por contraposição ao disponente, para compreender e comparar os vários clausulados predispostos disponíveis no mercado, cfr. JÜRGEN BASEDOW, Vorbemerkung, cit., nm. 5.

${ }^{10}$ Como veremos já de seguida em texto, esta inexigibilidade é concretizada por apelo a argumentos económicos, sendo crassamente ineficiente a aquisição de mais informação por parte do aderente, dados os custos desmesurados em tal implicados e a pouca plausibilidade do retorno associado - cfr. JOAQUIM DE SOUSA RIBEIRO, O problema... cit., pp. 349-354. Numa análise custos-benefícios, o comportamento maximizador do aderente é o de não adquirir a informação necessária à cabal avaliação das cláusulas, já que os custos de aquisição de informação são desmesurados face às vantagens potenciais daí resultantes, dada a "credível inegociabilidade das condições apresentadas" e, face à hipótese da procura de outro ofertante, face à inexistência no mercado, ou dispendiosa cognoscibilidade, de um ofertante que pratique condições diferentes. Trata-se - diríamos, para lá do que diz o autor - de uma situação de ignorância racional. Diferentemente, a aquisição de informação é claramente vantajosa para o utilizador, integrando-se na sua estratégia de planificação para a contratação massificada, já que aquele pode repartir tais custos por um sem número de contratos. Não se trata de uma situação de resignação do contraente a "submeterse, por falta de alternativas, a riscos de que está sabedor", mas antes da sua falta de "interesse em conhecer ao pormenor a regulação das vicissitudes relacionadas com a execução do contrato", centrando antes "a sua atenção nas utilidades que o seu objecto lhe pode proporcionar" (p. 354).

11 JoHAnNES KÖNDGEN, "Grund und Grenzem des Transparenzgebots im AGB-Recht, Bemerkungen zum "Hypothekenzins-" und zum "Wertstellungs-Urteil" des BGH", NJW 15 (1989), pp. 946-947; JOAQUIM DE SoUSA RIBEIRO, O problema... cit., pp. $354-355$ e $360-364$. Tal arreda o argumento que viesse rebater esta necessidade acrescida de tutela com a afirmação de que, em muitas outras actuais situações de aquisição de bens e serviços, o adquirente actua como um market taker, já os respectivos preços tão-pouco são apresentados à negociação, mas colocados numa lógica de "take it or leave it". Aliás, a concepção da liberdade contratual tem mesmo vindo a ser reconfigurada a esta luz: esta não pode ser realisticamente concebida como uma liberdade de co-conformação do contrato - como a concebem autores como Flume ou Emmerich. São muito enfáticas as palavras de ClAUS-WILHELM CANARIS, "Gesamtunwirksamkeit und Teilgültigkeit rechstgeschäftlicher Regelungen", in Festschrift für Ernst Steindorff zum. 70. Geburtstag am 13. März 1990, JÜRGEN F. BAUR, KLAUS J. HoPT, K. PETER MAILÄNDER (org.), Walter de Gruyter, Berlim/Nova Iorque, 1990, p. 548, a este respeito, segundo as quais a compreensão da liberdade contratual através de um modelo de negociação de todo o conteúdo do clausulado constituiria uma quimera ridícula, que, se explicava o que ocorria num bazar, não explicava já o funcionamento da actual economia de mercado. Trata-se aqui de uma deslocação do foco - a conformação das condições do negócio deixa de ser concebida como um acto bilateral de poder, para ser concebida em termos irremissivelmente institucionais. Cabe ao mercado, através do mecanismo da concorrência, e não à actuação do concreto contraente, influir no conteúdo das propostas. A liberdade contratual reduz-se aqui à mera possibilidade de uma opção informada entre várias alternativas, não podendo mais ser dissociada dos mecanismos da concorrência. Como tal, a sua protecção exige tanto uma actuação sobre o próprio mercado, procurando levá-lo a actuar de modo concorrencial - o que se faz pelos mecanismos de controlo da concorrência, atinentes ao Direito económico -, como uma actuação directa sobre as relações entre privados, suprindo os mecanismos do mercado em caso de falha deste.
} 
face à comparação entre os preços de cada uma, já que a sua análise é mais linear e que o consumidor foca nesse factor a análise que funda a sua escolha ${ }^{12}$.

Podemos, pois, concluir que a regulação das ccg visa compensar uma verdadeira falha de mercado ${ }^{13}$, evitando que a assimetria informativa que caracteriza o mercado provoque uma espiral de selecção adversa, expulsando os melhores clausulados do mercado ${ }^{14}$. Trata-se aqui de suprir, por via normativa, o papel da concorrência.

Se é assim por um lado, por outro tem quer ser salientada a indispensabilidade do recurso a ccg para assegurar o funcionamento das modernas estruturas de produção e distribuição. Sem uma estandardização dos próprios clausulados, não se assegura a racionalização de custos e planeamento necessários ao serviço de uma produção em massa dirigida a um consumo também massificado $^{15}$.

Perante este pano de fundo, atribui-se à regulação sobre ccg o escopo de proteger o aderente face a resultados desproporcionados derivados da conformação unilateral do clausulado pelo utilizador ${ }^{16}$.

\section{§ 2 O regime do controlo de conteúdo de ccg transposto para o contrato de seguro}

\section{Objecto do controlo}

Antes de avançarmos, deveremos dar nota de uma questão que poderia prejudicar a própria possibilidade de sindicância de uma parte substancial dos clausulados contratuais seguradores. Com efeito, o seguro é um "produto jurídico" cujas qualidades dependem exclusivamente do clausulado ${ }^{17}$. Assim, todas as cláusulas que procedem a um recorte primário (inclusivo) ou secundário (excludente) do risco transferido - pense-se nas cláusulas que definem o risco coberto, nas que estabelecem exclusões de cobertura, ou nas que estabelecem exigências de conduta ligadas ao risco ou ao sinistro - determinam a atribuição que fica a cargo do segurador.

A apreciação de tais cláusulas pareceria, pois, prima facie, contender com os termos da

\footnotetext{
12 JOAQUIM DE SOUSA RIBEIRO, O problema... cit., pp. 357-360.

${ }^{13}$ Salientando o escopo de correcção de falhas de mercado da legislação sobre ccg, JoHANNES KöNDGEN, "Grund...", cit.,, p. 946; mais recentemente, JÜRGEN BASEDOW, Vorbemerkung, cit., nm. 5-6; em sede geral, cfr. ainda MANFRED WOLF, JÖRG NEUNER, Allgemeiner Teil des bürgerlichen Rechts, C. H. Beck, Munique, 2012, pp. 552-553.

${ }^{14}$ JOAQUIM DE SOUSA RIBEIRO, O problema... cit., pp. 357-360.

${ }^{15}$ JAN SCHAPP, "Die Leitbildsfunktion des dispositiven Rechts für die Inhaltskontrolle von Allgemeinen Geschäftsbedingungen nach $\$ 9$ Abs 2 AGB-Gesetz", Der Betrieb (1978), pp. 622-624; ANTÓNIO PINTO MONTEIRO, "Contratos de adesão: o regime jurídico das cláusulas contratuais gerais instituído pelo Decreto-Lei n. ${ }^{\circ}$ 446/85, de 25 de Outubro", ROA 3 (1986), pp. 741-742;

${ }^{16}$ É esta a visão dominante na doutrina alemã - HARRY SCHMIDT, "BGB § 307 Inhaltskontrolle", Beck'scher Online-Kommentar BGB, HEINZ GEORG BAMBERGER, HERBERT RoTH (org.), Beck, Munique, 2015, disponível em http://beck-online.beck.de (04.07.2015), nm. 1.

${ }^{17}$ Usamos a fórmula difundida sobretudo por MEINRAD DREHER, Die Versicherung als Rechtsprodukt, Die Privatversicherung und ihre rechtliche Gestaltung, J. C. B. Mohr (Paul Siebeck), Tubinga, 1991, passim; para o reporte, também corrente na doutrina germânica, a uma delimitação do risco primária e secundária, cfr. ex multis, na doutrina recente, JürgEN PRÖLSS, "§ 1", Prölss/Martin Kommentar, C. H. Beck, Munique, 2010, disponível em http://beck-online.beck.de/ (18.02.2011), nm. 114.
} 
Directiva, que exclui a avaliação do carácter abusivo das cláusulas que respeitem à definição do objecto principal do contrato (art. $4 .^{\circ}$, n. $^{\circ} 2$ ), precisando, no considerando n. ${ }^{\circ} 19$, que, no caso de contratos de seguros, as cláusulas que definem ou delimitam claramente o risco segurado e o compromisso do segurador não são objecto de tal apreciação desde que essas limitações sejam tidas em conta no cálculo do prémio a pagar pelo consumidor ${ }^{18}$. A limitação constante do art. $4 .^{\circ}$, n. $^{\circ} 2$, foi expressamente acolhida pela generalidade dos Estados-membros; não assim por Portugal.

Trata-se de um parâmetro que concita o questionamento. Tanto é assim nos Estados que transpuseram a limitação, onde doutrina e jurisprudência não se eximem à procura de um espaço de actuação da sindicância, face a uma directriz que pareceria barrar de plano a sua interferência nesta sede - é assim na França ${ }^{19}$, e, como veremos de seguida, na Alemanha -; como é assim nos Estados que a não transpuseram, mas que se debatem com a garantia constitucional da livre iniciativa privada - é assim em Espanha, à face do art $38^{\circ}$ da Constituição ${ }^{20}$ e é assim em Portugal, à face do art. 61..$^{\circ}$ da CRP.

No ordenamento jurídico alemão, a limitação decorre actualmente do $§ 307$, III, do BGB, que sucedeu ao $\S 8$ da Lei sobre ccg, alinhando-o com as exigências de transparência

\footnotetext{
${ }^{18}$ José CARlos Moitinho de Almeida, "Cláusulas contratuais gerais e contrato de seguro", in Contrato de seguro, Estudos, J. C. MoitinHo DE ALMEIDA (org.), Coimbra Editora, Coimbra, 2009, pp. 93-94, dando conta de que a limitação atendeu à pressão de alguns Estadosmembros, que consideraram que a avaliação destas cláusulas contenderia com a garantia constitucional dos princípios da economia de mercado.

${ }^{19}$ No Direito francês, uma cláusula pode ser reputada abusiva, e por isso não escrita, uma vez cumpridas três condições cumulativas: a cláusula não deve ser atinente ao objecto principal do contrato (Code de la consommation, L 132-1, al. 7); a cláusula deve ter por efeito a criação, em detrimento do não profissional, de um desequilíbrio significativo entre os direitos e as obrigações das partes no contrato (L 132-1, al. 1); e o contrato de seguro não deverá ser atinente à actividade profissional do segurado (L 132-1, al. 1). Debatendo-se directamente com a questão, Leduc em Hubert Groutel, FABrice Leduc, PhilipPe PIERRE, MAUd Asselain, Traité du contrat d'assurance terrestre, LexisNexis, Paris, 2008, p. 532, procura um meio de manter as cláusulas que criam deveres de prevenção do risco acessíveis ao controlo de conteúdo. Uma das vias seria, convocando o citado Considerando da Directiva para interpretar o art. art. L 132-1, al. 1, defender que apenas as situações de imposição de deveres que tenham sido tomadas em conta para cálculo do prémio deverão ser excluídas da fiscalização. O autor rejeita, porém, essa via. Desde logo, porque tal implicaria, ao contrário do assumido, afinal uma fiscalização da adequação prémio/risco - já que se trataria de aferir do carácter abusivo de cláusulas que, sendo limitativas do risco assumido, não tinham sido contempladas numa descida de prémio. A outra objecção levantada é de índole pragmática: dada a extrema complexidade dos cálculos subjacentes ao prémio, seria extremamente difícil destrinçar o que tinha e o que não tinha influído nesse cálculo. Uma outra via, proposta pelo autor, assenta na outorga de uma certa ratio legis ao preceito que estabelece esse limite. Considera o autor que, com a imposição dessa barreira à fiscalização, do que se trata é de evitar que se faça desaparecer do contrato cláusulas essenciais à subsistência deste-provocando-se, pois, por uma via que se queria protectiva do segurado, a pioria da sua situação, já que este seria deixado sem contrato e, como tal, sem cobertura. Perante este raciocínio, desaparecem os obstáculos à fiscalização destas cláusulas que impõem condutas preventivas, já que a sua erradicação do contrato não põe em causa a subsistência deste: o contrato subsiste, com o mesmo prémio, limitando-se o intérprete a despojá-lo dos deveres abusivos.

${ }^{20}$ No Direito espanhol, a protecção por via do Direito dos seguros adiantou-se à protecção especificamente dirigida ao fenómeno das cláusulas contratuais gerais, vindo o art. $3 .^{\circ}$ da LCS cuidar a tutela do segurado contra as "condiciones generales" antes da aprovação da "Ley sobre condiciones generales de la contratación" (Lei n. ${ }^{\circ}$ 7/98). Entende-se actualmente que o art. $3 .^{\circ}$ da LCS vale como disposição especial face à segunda (FERNANDO SÁNCHEZ CALERO, "Art. 3. Condiciones generales", in Ley de contrato de seguro. Comentarios a la Ley 50/1980, de 8 octubre, y a sus modificaciones, FERnANDO SÁNCHEZ CALERO (org.), Aranzadi, Cizur Menor, 2010, pp. 108-109). Ora, a conciliação do art. 3. ${ }^{\circ}$ da LCS com o disposto no art. $1^{\circ}$, que determina que o segurador deve prestar dentro dos limites convencionados, como a tomada em consideração da disposição da Directiva de que dizemos em texto, reflectiram-se numa tomada de posição doutrinal e depois jurisprudencial quanto à questão (a paternidade do critério geralmente seguido é atribuída a Sánchez Calero - FRANCISCO JAVIER TIRADO SuÁREZ, "Cláusulas abusivas y contrato de seguro en Derecho español", in Congresso luso-hispano de Direito dos seguros, Almedina, Coimbra, 2009, p. 193; veja-se a jurisprudência aí citada nas pp. 184 e ss.), que apartou as cláusulas limitativas de direitos do segurado, sujeitas a escrutínio, de cláusulas delimitadoras da prestação, dele isentas. As últimas são descritas como as que concretizam o objecto do seguro, determinando os riscos cuja concretização dá origem à obrigação de prestar do segurador, determinando o risco que se cobre, por que quantia, e em que limites temporais ou espaciais; as cláusulas limitativas são as que restringem os direitos do segurado, operando uma vez que esteja concretizado o objecto do seguro (FERNANDO SÁNCHEZ CALERO, "Art. 3", cit., pp. 134-138). É um critério de pouco préstimo face à facilidade com que se amolda o texto de uma cláusula a uma função ou outra.
} 
referidas na Directiva ${ }^{21}$. Fundamento primacial do preceito é a defesa dos princípios da economia do mercado, implicando que, salvo em caso de falha de mercado, cabe aos ofertantes a livre conformação dos produtos que nele colocam. Ora, mobilizando esta ratio do preceito, e invocando ainda a liberdade de consagração de um standard de protecção mais elevado pelos legisladores dos Estados-membros, a doutrina e a jurisprudência não se acolhem a uma isenção de plano da fiscalização do conteúdo das ccg. Entende-se que a complexidade da conformação do produto "seguro" leva a que o adquirente médio tome apenas em consideração, na sua escolha no mercado, as características verdadeiramente nucleares do contrato - pelo que apenas a interferência nestas seria apta a colidir aqui com o funcionamento da economia de mercado $^{22}$. Reconhece-se ainda, face a tal complexidade e ao facto de o segurado não estar de antemão em condições de precisar qual a probabilidade de fazer uso da cobertura que adquire, que o segurador tem em relação a ele uma responsabilidade especial na conformação do seu produto $^{23}$. Assim, isentas de controlo estão apenas as cláusulas sem as quais o conteúdo do contrato careceria de um mínimo de determinabilidade, sendo como tal nulo ${ }^{24}$. Incluem-se aqui, de um modo geral, as cláusulas que definem o tipo de seguro, o montante da cobertura, o dever de pagar o prémio e a sua relação com a cobertura contratada; sem que se possa porém dizer que mesmo estes redutos estão vedados do controlo de conteúdo, não hesitando a jurisprudência em considerar as cláusulas como modificativas do risco coberto e, como tal, fiscalizáveis ${ }^{25}$.

Este entendimento, que é também o espelhado nos $\mathrm{PEDCS}^{26}$, tem sido acolhido pela doutrina nacional, que considera que tão-pouco o nosso ordenamento deve ser alheio a ditames de proporcionalidade face à garantia da livre iniciativa económica do segurador, devendo as cláusulas que conformem, nesse sentido, o núcleo do contrato, estar eximidas a um controlo de conteúdo $^{27}$. Em todo o caso, de acordo com os termos da Directiva, a inscrição no âmbito do

\footnotetext{
21 Andreas Fuchs, "§ 307 Inhaltskontrolle ", in AGB Recht Kommentar, PeTER Ulmer, HANS E. BRANDNER, HoRst-DiETHER Hensen (org.), Dr. Otto Schmidt, Colónia, 2011, pp. 574, 576-578, também quanto ao que dizemos de seguida.

22 ANDREAs FuCHS, "§ 307", cit., pp. 598-599.

23 JÜRgEN PRÖLSS, I. Rechtsgrundlagen des Versicherungsvertrages, cit., nm. 78, com o seguinte paralelo expressivo: o segurado que adquire cobertura seguradora não pode ser comparado com o adquirente de um carro pequeno, que se não poderá legitimamente surpreender se o carro que adquire não tem as qualidades de um carro grande.

24 ANDREAS FUCHS, "§ 307", cit., p. 598, e, para além da jurisprudência aí citada, ex multis, ac. do BGH de 21.04.1993, IV ZR 33/92, nm. 15-16.

25 UlRICH HüBNER, "Auswirkungen der europarechtlich vorgegebenen Änderungen des AGB-Gesetzes und des Versicherungsaufsichtsrechts auf die richterliche Kontrolle von Allgemeinen Versicherungsbedingungen", in Karlsruher Forum 1997, Das Recht der allgemeinen Geschäftsbedingungen nach der Umstezung der EG-Richtlinie über mißbräuchliche Klauseln in Verbraucherverträge, Verlag Versicherungswirtschaft, Karlsruhe, 1998, pp. 58-59, considerando fútil a discussão destes limites, já que, na prática, a jurisprudência não se coibia de controlar o conteúdo de qualquer tipo de cláusula quando entendia dever fazê-lo - e, na verdade, a doutrina recente confirma a escassez de decisões judiciais que se escudam na limitação dos poderes de controlo (ANDREAS FUCHS, "§ 307", cit., p. 600).

${ }^{26}$ Art. 2:304, 3). Cfr. Project Group Restatement of European Insurance Contract Law, Principles...2015, cit., p. 143, comentário C4, considerando que apenas as cláusulas nucleares estão eximidas ao controlo de conteúdo, consistindo elas nas cláusulas que "give a crucial definition or circumscription of the type and subject of insurance, the insured risk, the insurer's liability, the insurance benefit, the sum insured, the insured interest or the insurable value".

${ }^{27}$ José CARlos MoitinHo DE AlmeidA, "Cláusulas...", cit., pp. 95-96.
} 
controlo deve voltar caso a cláusula não se encontre redigida de modo claro e compreensível promovendo-se esta transparência, promove-se então a concorrência, que, na verdade, aquela isenção vinha salvaguardar ${ }^{28}$.

Este controlo incide, pois, por exemplo, sobre a generalidade das cláusulas que conformam o risco coberto - quer sejam abertamente redigidas como exclusões, quer, tendo embora esse sentido, venham formuladas pela positiva ${ }^{29}$, quer, enquadrando-se ainda na dita delimitação secundária do risco, venham criar deveres de controlo do risco. É, aliás, no âmbito que se diria deste ponto de vista mais melindroso, atinente às cláusulas de exclusão do risco, que a jurisprudência nacional vem em grande medida exercendo o seu magistério ${ }^{30}$.

\section{Parâmetro do controlo}

O parâmetro central de valoração do conteúdo das cláusulas contratuais gerais é, perante o RJCCG, por influência germânica (veja-se, hoje, o § 307, I, do BGB), o da boa fé (art. 15. ). Vemos aqui o parâmetro a actuar, pois, fora da sua função de norma de conduta, como norma de validade de convenções privadas, valendo numa função limitativa e correctora ${ }^{31}$.

Entre nós, o critério geral da boa fé é recebido na lei sem que esta forneça parâmetros claros de concretização. Após uma referência ao fundamento do controlo, no corpo do art. $16^{\text {o }}$ - atinente aos valores fundamentais do Direito -, aponta-se, nas suas especificações, em dois sentidos diversos. Por um lado, para uma tutela da confiança concretamente gerada nas circunstâncias da contratação. Por outro, para uma tutela que se coloca mesmo para lá das circunstâncias concretas da contratação, em relação à compatibilidade da cláusula com o objectivo que as partes visaram atingir negocialmente. A sua determinação efectiva-se, antes

\footnotetext{
${ }^{28}$ JÜRGEN BASEDOW, "Transparenz als Prinzip des (Versicherungs-)Vertragsrechts", VersR (1999), p. 1048.

${ }^{29}$ Coisa diversa não vale, de resto, no ordenamento alemão, onde se sublinha a sujeição ao controlo das próprias cláusulas de delimitação do risco formuladas pela positiva, desde que venham excluir a cobertura de riscos que, de acordo com a lei ou com a boa fé em atenção aos usos do tráfico, se devessem entender incluídos na cobertura, limitando ou modificando a prestação que o tomador poderia, em face da finalidade do contrato, legitimamente esperar - cfr. ANDREAS FUCHS, "§ 307", cit., p. 599, reportando-se a Brandner.

${ }^{30}$ Cfr., por exemplo, Ac. do STJ de 7 de Outubro de 2010, Processo n. ${ }^{\circ}$ 1583/06.7TBPRD.L1.S1; ac. do STJ de 27 de Maio de 2010 , Processo n. ${ }^{\circ}$ 976/06.4TBOAZ.P1.S1 (sumário); mais recentemente, ac do TRL de 26 de Fevereiro de 2013, Processo n. ${ }^{\circ}$ 411/10.3TBTVD.L1 -7. Tratase aqui do escrutínio de cláusulas que delimitam o risco em sede de seguros de invalidez contratados para garantia do crédito, considerandose que são nulas as cláusulas que requeiram, para que dê por verificada a invalidez, que a pessoa segura se encontre em estado de impossibilidade de subsistência funcional sem apoio de terceira pessoa. Cfr. ainda ARNALDO DA CostA OLIVEIRA, "Cláusulas abusivas e o contrato de seguro", in Congresso luso-hispano de Direito dos seguros, Almedina, Coimbra, 2009, pp. 238-239, considerando que se trata aqui de compensar a falta no ordenamento nacional de uma disposição análoga ao art. L113-1 do Cod. Ass. ou ao art. 3. ${ }^{\circ}$ da LCS, que estabelecem limites às cláusulas de exclusão.

${ }^{31}$ JOAQUIM DE SOUSA RIBEIRO, O problema... cit., pp. 546 e ss., JOAQUIM DE SOUSA RIBEIRO, "'Economia do contrato", autonomia privada e boa fé", in Ars iudicandi, Estudos em homenagem ao Prof. Doutor Jorge de Figueiredo Dias, IV, Coimbra Editora, Coimbra, 2010 , pp. 976-977. Este alargamento da boa fé para lá das suas funções tradicionais, de norma de conduta com vocação individualizada, prende-se com a delimitação recíproca do parâmetro face à cláusula alemã dos bons costumes, guardiã do cerne de valores de um ordenamento perpassado de pré-compreensões liberais. Tal levou à busca de um critério flexível, que pudesse valorar práticas legítimas perante o parâmetro dos bons costumes, mas que, aqui, perante os riscos colocados pelo recurso a cláusulas contratais gerais e a falha de mercado que estas exprimem, devem ser tidas por ilegítimas. O parâmetro da boa fé revelou-se o procedente nesta sede por a contratação com recurso a contratos predispostos se revelar uma forma de exercício de poder sobre os co-contratantes, advindo daí um especial dever de tomar em consideração os interesses da contraparte. Cfr. JOAQUIM DE SOUSA RIBEIRO, O problema... cit., especialmente pp. 542 e ss.
} 
de mais, à luz da regulação do tipo contratual, que, quando se trate de tipo legal, vale, nas suas disposições imperativas e supletivas, como modelo de controlo ${ }^{32}$; já na densificação um tipo social, têm relevo os usos do tráfico. Em formações contratuais que não tenham respaldo num tipo pré-disponível, o relevo cabe às finalidades contratuais reconhecidas por ambas as partes ${ }^{33}$.

O modelo subjacente ao tipo não vem em qualquer caso convocado em si, como puro argumento formal, mas como precipitado dos valores fundamentais do Direito numa ordenação típica de interesses que funda expectativas em quem a mobiliza. Estes dois vectores conciliamse na ideia de que cabe atentar na cláusula não em si, isoladamente, mas de acordo com o sentido que esta recolha do concreto contrato em que se insere ${ }^{34}$.

Cabe ao princípio da boa fé, como norma de validade, encaminhar para a sede concreta os "valores fundamentais do Direito" referidos no corpo do art. 16. ${ }^{\circ}$ Faltaria aqui ainda uma ponte de concretização entre o sentido geral da boa fé e essa sua concretização na preservação do objectivo ou sentido e fim do contrato, não sendo metodologicamente defensável, - ou sequer, face aos dados legais, possível - uma aplicação mecânica da regulação do tipo ${ }^{35}$. Tal ponte, dá-a o princípio da proporcionalidade. Tal é claro na Directiva, que exige um desequilíbrio significativo dos direitos e deveres dos contraentes, em prejuízo do consumidor. À face da lei portuguesa, a doutrina chega a esse mesmo resultado, através da conjugação entre a cláusula geral da boa fé e as suas concretizações nas alíneas do art. $16 .^{\circ}$ e atenta a teleologia do controlo dos clausulados. Entende-se que se trata aqui de buscar um adequado equilíbrio num contexto de ponderação de interesses: de um lado, os interesses de racionalização, certificação e uniformização do predisponente; e, do outro, os interesses da contraparte, tal como resultam de uma consideração aprofundada das normas legais e princípios aplicáveis à

\footnotetext{
${ }^{32}$ ALMENO DE SÁ, "Lei das cláusulas contratuais gerais e Directiva sobre cláusula abusivas", in Cláusulas contratuais gerais e Directiva sobre cláusulas abusivas, ALMENO DE SÁ (org.), Almedina, Coimbra, 2001, pp. 36-37, considerando exactamente que a sua densificação implica a convocação do tipo negocial em causa, com vista a determinar se a estipulação não leva ao malogro do que é normalmente intendido face ao tipo negocial em causa.

${ }^{33}$ Defendendo uma mobilização de parâmetros diferenciados à medida que nos afastamos dos tipos, MANFRED WOLF, JÖRG NEUNER, Allgemeiner... cit., p. 566. Sempre se diga, porém, que uma determinação daquelas finalidades contratuais mutuamente reconhecidas, de acordo com a teoria da impressão no destinatário, remeterá novamente amiúde para aqueles outros parâmetros de índole objectiva, atinentes aos usos do tráfico e normas legais que compõem os tipos.

${ }^{34}$ HARRY SCHMIDT, $\$ 307$, cit., nm. 21.

${ }^{35}$ JOAQUIM DE SOUSA RIBEIRO, O problema... cit., pp. 578 e ss.
} 
situação em causa ${ }^{36}{ }_{-}^{37}$.

Esses interesses a sopesar devem ser especificamente concretizados no que ao Direito dos seguros concerne. Do lado do segurado, interfere com grande acuidade o interesse na obtenção da maior cobertura possível face ao risco em causa. O facto de a obter ao menor preço não é contudo, em si, objecto de tutela em sede de aplicação do diploma das cláusulas contratuais gerais, sendo antes deixado ao mercado. Mas deve valorar-se já o facto de a manutenção de tal cobertura postular limitações relevantes da liberdade patrimonial e pessoal - em atenção aos direitos de personalidade - do segurado ${ }^{38}$. Entram neste lado da ponderação também os interesses dos outros sujeitos ligados ao risco, como o segurado, quando diferente do tomador, ou os beneficiários, quando os houver ${ }^{39}$.

Do lado do segurador, têm especial incidência os referidos interesses na racionalização e uniformização da oferta do produto jurídico "seguro" - já que, aqui, surgem ligados à própria técnica da mutualização dos riscos, que pressupõe a possibilidade de cálculo antecipado ${ }^{40}$. A par com estes, poder-se-ia também aduzir um interesse na contenção do preço oferecido e do risco coberto em contrapartida - aqui flanqueado não só pela maior vulnerabilidade a fenómenos de selecção adversa por parte do segurador que menos compartimente os riscos cobertos, como pelo facto de o encarecimento dos prémios cobrados em atenção à cobertura de mais riscos implicar do mesmo passo uma oneração acrescida da comunidade de segurados.

Tal como em geral, salienta-se, porém, que este interesse não pode desde logo trunfar irrestritamente sobre o interesse em obter uma cobertura adequada às necessidades servidas

\footnotetext{
${ }^{36}$ Coube a MiChael STÜRnER, Der Grundsatz der Verhältnismäßigkeit im Schuldvertragsrecht, Zur Dogmatik einer privatrechtsimmanenten Begrenzung von vertraglichen Rechten und Pflichten, Mohr Siebeck, Tubinga, 2010, especialmente pp. 346 e ss. e 383 e ss., uma recente proposta de enquadramento do princípio da proporcionalidade como princípio reitor do Direito das obrigações. O autor propõe fundamentalmente a mobilização do princípio da proporcionalidade em sentido estrito enquanto princípio jurídico autónomo, com fundamento geral, e não enquanto derivação das suas concretizações no Direito público. Trata-se de um meta-princípio de puro carácter procedimental, sem conteúdo próprio, que opera em situações de conflito: quanto o decidente se encontre perante várias alternativas e seja necessário um critério racional para decidir por uma delas, o princípio permite-lhe reunir, sopesar e comparar argumentos. A ponderação faz-se nos termos de um sistema móvel, permitindo a mobilização dos diversos pontos de vista, não definidos à partida, de um modo graduado. O princípio vem fundado na justiça comutativa, enquanto corporização da justa medida: trata-se do reverso do princípio da igualdade, valendo como proibição da desigualdade excessiva. Para o que aqui importa, face à convocação do parâmetro para fiscalização do conteúdo de cláusulas atinentes a deveres laterais, trata-se aqui de uma ponderação entre os interesses do utilizador e do aderente (p. 387). Nesta, o critério material da justiça é dado "pelo contrato" - ou seja, pelo seu regime dispositivo, que representa o que as partes acordariam como ordenação justa dos seus interesses. Aludindo ao princípio da proporcionalidade em sentido estrito como a vertente mais pertinente para mobilização em sede jurídico-privada, DULCE LOPES, O princípio da proporcionalidade no Direito comunitário, Uma perspectiva de controlo, s. ed., Coimbra, 2003, p. 60.

${ }^{37}$ Assim, Almeno de SÁ, "Lei... ", cit., p. 35; também JoAquim de SouSA RiBEIRO, O problema... cit., pp. 570 e ss.: o termo de comparação é uma adequada composição de interesses. Na doutrina alemã, cfr., similarmente, MANFRED WOLF, JÖRG NEUNER, Allgemeiner... cit., p. 567, dizendo que, em primeiro lugar, é necessário determinar a existência de desfavorecimento, em atenção às circunstâncias que se verificariam sem a dita cláusula; seguidamente, deve determinar-se se tal desfavorecimento falha o teste da adequação, servindo então de parâmetro o princípio da boa fé, que determina que, num contrato, cada parte deve poder esperar uma distribuição equilibrada dos direitos, oportunidades e riscos de cada uma.

${ }^{38}$ AleXAnder Bruns, "BGB $\S 307$ Inhaltskontrolle", MüKo $V V G, I$, TheO LANGHEID, Manfred WandT (org.), C. H. Beck, Munique, 2010, disponível em http://beck-online.beck.de (26.02.2011), nm. 58; HARRY SCHMIDT, § 307, cit., nm. 38.

${ }^{39}$ ALEXANDER BRUNS, $\$ 307$, cit., nm. 58.

${ }^{40}$ Relativizando tais interesses em termos gerais, HARRY SCHMIDT, \$ 307, cit., nm. 31; afirmando a sua acuidade em sede seguradora, AlEXANDER BRUNS, $\S 307$, cit., nm. 59. Cfr. ainda, também quanto ao que dizemos já de seguida, JÜRGEN PRÖLSS, I. Rechtsgrundlagen des Versicherungsvertrages, cit., nm. 18, salientando que não se trata aqui de um mero interesse de racionalização para contenção de custos, encontrando-se antes ligado à natureza do bem e técnica que lhe subjaz.
} 
pelo seguro. Não é adequada a solução que privilegie à outrance a oferta do produto segurador ao preço mais baixo possível - importa, sim, que o produto tenha as qualidades necessárias à satisfação daquelas necessidades ${ }^{41}$. Assim, a título de exemplo, no que concerne às questões levantadas pelas exigências de conduta ligadas ao risco, é argumento amiúde esgrimido o de que à generalidade dos segurados interessa obter cobertura quanto a situações normais de desatenção na relação com os riscos cobertos.

Nem procede o argumento segundo o qual a concessão de uma irrestrita liberdade de conformação da cobertura levasse a resultados mais sãos do ponto de vista do mercado. Devemos lembrar que a assimetria informativa não existe num só sentido: face ao conteúdo dos clausulados, desfavorece assinalavelmente os segurados, levando-os a contratar apenas com base no preço da cobertura, sem conseguirem escrutinar cabalmente a qualidade do que adquirem. Assim, o efeito da degradação do conteúdo da cobertura é aqui o da selecção adversa, correspondendo a uma "race to the bottom"42. Tal colocaria obviamente problemas quando não interferisse qualquer normação, sequer supletiva, nos termos da cobertura, já que levaria tendencialmente a que apenas os piores ofertantes permanecessem no mercado. E coloca problemas ainda quando o "ponto focal" - olhemo-lo para já assim, pois estamos exactamente a problematizar o degrau prévio à sua convocação como Leitbild - colocado pelas normas supletivas dê margem ao segurador para se evadir à cobertura. Com efeito, aqui a celebração de um contrato em que não existisse tal possibilidade reflectir-se-ia no preço, tendendo a atrair os piores co-contratantes.

Na busca do ponto de equilíbrio da ponderação dos interesses em causa tem, como vimos, um relevo determinante o modelo dado pela regulação imperativa e dispositiva do tipo legal ${ }^{43}$. E tem-no em dois planos. Num primeiro plano, a referência imediatamente feita ao todo

\footnotetext{
${ }^{41}$ Por todos, em sede geral, relativamente ao "Preisargument", HARRY SCHMIDT, $\S 307$, cit., nm. 33: "Es gilt das Postulat, dass es die Kehrseite der Preisgestaltungsfreiheit des Verwenders ist, seine Preise so zu kalkulieren, dass sich seine vertraglichen Verpflichtungen im Rahmen der Gebote von Treu und Glauben eben erfüllen lassen". De resto, como salienta o autor, os processos de tarificação dos produtos não são transparentes ao ponto de permitir que este elemento entre num verdadeiro escrutínio.

${ }^{42}$ LAW COMMISSION/SCOTTISH LAW COMMISSION, Insurance contract law: Business disclosure; warranties; insurer's remedies for fraudulent claims; and late payment 2014, disponível em http://www.lawcom.gov.uk/project/insurance-contract-law-business-disclosure-warrantiesinsurers-remedies-for-fraudulent-claims-and-late-payment/ (03.03.2015), pp. 12-13.

${ }^{43}$ Cfr. Karl Larenz, Richtiges Recht, C. H. Beck, Munique, 1979, pp. 76-79, vendo aqui exactamente um afloramento da justiça contratual, atinente à ideia de equilíbrio na relação entre as partes. No Direito positivo alemão, cfr. o $\$ 307$, II, do BGB. Nos termos deste, deve na dúvida concluir-se pela existência de um desfavorecimento desproporcionado quando uma cláusula não seja conforme a ideias-base ("Grundgedanken", e não "Grundsätze") essenciais da regulação legal que derroga (1), ou quando limite de tal modo direito e deveres essenciais, decorrentes da natureza do contrato que coloque em risco a consecução da sua finalidade (2), ou quando não seja clara e compreensível (3). Este último ponto diz respeito ao controlo da transparência; já com os arts. $15 .^{\circ}$ e $16 .^{\circ}$ do RJCCG dialogam directamente os dois números anteriores. Não é evidente descobrir um sentido útil para cada um desses números, já que a colocação em causa de direitos ou deveres essenciais à luz da natureza do contrato sempre seria desconforme às ideias essenciais da dita regulação (quanto ao papel desempenhado no seu surgimento pela jurisprudência atinente aos "Kardinalpflichten", cfr. infra). Perante a impressão de que haveria que "procurar à lupa" a diferença entre o alcance de um e de outro destes números (WoLfGANG WURMNEST, "BGB § 307 Inhaltskontrolle", MüKo BGB, II, Schuldrecht, Allgemeiner Teil, $\$ \$ 241-432$, WolfGANG KRÜGER (org.), C. H. Beck, Munique, 2012, disponível em http://beck-online.beck.de (22.04.2014), nm. 70), a doutrina tem envidado esforços para alocar a cada um deles um sentido autónomo. Assim, considera-se que $\S 307$, II, 2, visa especificamente as cláusulas relativas a contratos para os quais não esteja disponível um modelo de regulação típica e que não possam tão-pouco colher esse modelo da aplicação analógica do regime previsto para um negócio similar (é a opinião generalizada; por todos, WOLFGANG WURMNEST, $\S 307$, cit., nm. 70). Esta consideração deixa porém imediatamente um outro
} 
de sentido formado pela regulação do tipo permite inferir o objectivo que as partes visam tipicamente atingir negocialmente, e que podemos também designar, ao modo alemão, como sentido e finalidade do contrato. Este prende-se, como foi já decorrendo da exposição, com uma visão normativizada da finalidade económica da operação económica, vista desta feita de um plano abstracto-tipificado e não concreto - de acordo com o horizonte de expectativas do contraente médio a que é dirigido o clausulado. É este todo de sentido que não deve ser em qualquer caso perdido de vista na ponderação.

Para lá deste passo, a cláusula controvertida pode sobrepor-se especificamente ao conteúdo de uma disposição supletiva, que vem então afastar. Neste caso, o modelo da regulação típica valerá sobretudo pelo seu conteúdo regulatório: impende sobre a ccg que se afastou da normação supletiva a suspeita de vir favorecer desproporcionadamente os interesses do disponente, fazendo-o à custa dos interesses do aderente. Por força dos riscos inerentes à utilização de ccg, o Direito dispositivo adquire assim uma rigidez que não lhe corresponderia à $\operatorname{partida}^{44}$.

Não havendo norma supletiva que regule a matéria de que cura a cláusula em apreço, terá esta que ser valorada na sua compatibilidade com o fim do contrato, à luz de argumentos teleológicos retirados, em primeira linha, do todo do regime típico; e, para lá destes, das demais normas e princípios do sistema que possam ser solicitadas em reforço da posição de ambas as partes - vg., de protecção dos seus direitos fundamentais.

\footnotetext{
problema em aberto: o da falta de um critério para valorar as cláusulas controvertidas (MORITZ RENNER, "Die „Natur des Vertrags“ nach $\$ 307$ Abs. 2 Nr.2 BGB", AcP 213 (2013), pp. 681 e ss.). A norma em análise decorre da jurisprudência do BGH atinente às "Kardinalpflichten", definidas de um modo muito genérico como "Pflichten, deren Erfüllung die ordnungsgemäße Durchführung des Vertrages erst ermöglicht und auf deren Erfüllung der andere Teil vertraut und vertrauen darf". Na busca de um critério para a sua identificação, o BGH assenta em dois níveis diversos: busca as obrigações nucleares à luz do escopo do concreto contrato celebrado; e busca do mesmo passo extraí-las das valorações legais. Aqui, vê a doutrina a convocação de duas fundamentações metodologicamente incompatíveis, o que não viria em auxílio do intérprete que buscasse um sentido autónomo para o § 307, II, 2. Este sentido tem sido procurado por alguma doutrina na valoração de uma abordagem sociológica do Direito, atinente à tutela de expectativas de facto colocadas na contratação, numa leitura influenciada pelas teorias dos "relational contracts" (Oechsler e, na sua esteira, MORITZ RENNER, "Die „Natur...", cit.,, pp. 683 e ss.) Não curamos especificamente desta problemática em texto, já que o que nos ocupa é a correcta mobilização do "Leitbild" fornecido pela existência de uma regulação típica; sempre se diga, porém, que a acentuação do elemento sociológico e do carácter meramente fáctico das expectativas tuteladas, se trazem ao jurídico a necessária atenção à virtualidade performativa da prática, não podem permitem que se perca de vista que se cura ainda de questões jurídicas, constitutivas do sistema jurídico, e que por isso têm um sentido também normativo, e não exclusivamente empírico (FERNANDO JOSÉ PINTO BRONZE, A metodonomologia entre a semelhança e a diferença, (Reflexão problematizante dos pólos da radical matriz analógica do sistema jurídico), Coimbra Editora, Coimbra, 1991, pp. 81-82).

${ }^{44}$ Deve fazer-se notar que o parâmetro das opções de regulação contidas no Direito supletivo não teve acolhimento nas normas do DCFR. Com efeito, no esquema tripartido de fiscalização adoptado pelo instrumento, o parâmetro é remetido para as cláusulas gerais da boa fé face à criação de desvantagens significativas, quer nos contratos entre empresas e consumidores (art. II-9:403), quer nos contratos entre sujeitos que não sejam empresas (II-9:404); já face aos contratos entre entes empresariais (II-9:405), vale o parâmetro do desvio grosseiro da cláusula face às boas práticas comerciais, quando tal seja contrário à boa fé. Diga-se, desde logo, que esta tripartição dos parâmetros não passa ao largo da crítica, quer por sugerir a leitura de que o conceito de justiça ("fairness") subjacente a cada ponderação é diverso (THOMAS PFEIFFER, "Non-negotiated terms", in Common Frame of Reference and existing EC Contract law, REINER SCHULZE (org.), Sellier, Munique, 2008, pp. 178-179), quer, adicionalmente, por colocar no mesmo patamar de gravidade um desvio, ainda que grosseiro, às boas práticas comerciais e a criação de desvantagens significativas para uma das partes (HORST EIDENMÜLLER, "Party autonomy, distributive justice and the conclusion of contracts in the DCFR", ERCL 2 (2009), pp. 129-130). Acresce que tal afastamento não convence autores como PHILLIP HELLWEGE, "Die $\$ \S 307-309$ enthalten zwei Formen der Inhaltskontrolle", cit., p. 1136. Por um lado, porque os parâmetros alternativos oferecem menos garantias em termos de segurança jurídica - nem as cláusulas gerais ganham em concretude, mais ainda num plano transnacional, antes de terem uma consistente concretização jurisprudencial, nem os usos do tráfico comercial são dotados de maior densidade, mais ainda atendendo ao seu carácter muitas vezes regional. Acresce que na base da aplicação alargada do Direito supletivo está uma presunção da sua justeza - presunção de que os usos do comércio não gozam.
} 
Em todo o caso, não se trata de um juízo fechado, mas de uma ponderação. E esta implica desde logo que se tenha em atenção o modo como esse quadro regulatório é mobilizado pelo concreto recorte das prestações principais. A recondução dos contratos aos tipos não é monolítica, havendo que alinhar o concreto contrato celebrado no plano do tipo, determinando se configura uma manifestação central ou periférica ou se deve ser reconduzido a um sub-tipo. Assim, por exemplo, o juízo atinente à exclusão da cobertura de despesas urgentes derivadas de um episódio agudo de doença pré-existente não será idêntico quando se trate de um seguro de saúde em viagem - postulando a utilidade da cobertura a sua inclusão - ou quando se trate de um seguro de saúde privado e complementar da oferta do Serviço Nacional de Saúde, como o poderão ser os do nosso ordenamento ${ }^{45}$.

Por outro lado, este mesmo carácter prudencial do juízo não implica que se aplique de plano toda a norma de Direito supletivo derrogado - de outro modo, levar-se-ia este a factor de petrificação da evolução do sistema jurídico - ou que se atribua a mesma força vinculativa a todas essas normas. O Direito supletivo é aqui convocado por corresponder à diagonal da ponderação ajustada dos interesses em presença, e por, face às falhas de informação que rodeiam a contratação com recurso a ccg, corresponder a uma tutela objectivizada de expectativas face ao regime aplicável. Trata-se de um juízo de grau: quanto maior o afastamento face ao Direito supletivo aplicável, maior a suspeita de inequitatividade ${ }^{46}$ - sendo, em todo o caso, de admitir que uma previsão que se afaste num sentido desfavorável do regime supletivo seja compensada pela inscrição de cláusulas de maior favor, em conexão material com aquela. De resto, estes fundamentos não se verificam quando o Direito supletivo em causa tiver meras funções de clarificação e desoneração e o segurador tenha cumprido o seu ónus de tornar cognoscível o conteúdo do contrato ao segurado - pense-se, face ao art. 39. ${ }^{\circ}$ do RJCS, na convenção, feita com transparência, segundo a qual o seguro produz efeitos a partir das 0 horas do segundo dia imediato ao da celebração ${ }^{47}$.

\footnotetext{
${ }^{45}$ Veja-se o ac. do BGH de 02.03.1994, IV ZR 109/93, que considerou contrária ao fim do contrato de seguro de saúde em viagem a cláusula que excluía a cobertura de riscos atinentes a doenças que estivessem já em estado agudo, sendo carecidas de tratamento, ainda antes do início da cobertura - já que, por um lado, o segurador não poderia eximir-se por esta via ao seu ónus de avaliar devidamente o risco; e, por outro, tal equivaleria a recusar a cobertura exactamente quando o segurado apenas a ela podia recorrer (cfr. sobretudo p. 1536).

${ }^{46}$ MiCHAEL StÜRNER, Der Grundsatz... cit., pp. 118-119. Permanece sempre aberta a possibilidade de prova de que a regulação adoptada pelo contrato, conquanto se afaste da regulação supletiva, não tenha em menor consideração os interesses do cliente (JÜRGEN PRÖLSS, $I$. Rechtsgrundlagen des Versicherungsvertrages, cit., nm. 72; quanto ao que dizemos de seguida, relativamente à compensação de desvantagens, nm. 75).

${ }^{47} \mathrm{Na}$ Alemanha, a jurisprudência convoca em geral a distinção entre as normas dispositivas a que corresponda um conteúdo de justiça ("Gerechtigkeitsgehalt") e aquelas a que corresponda uma racionalidade estratégica ("Zweckrationalität"), considerando que a rigidez do Direito supletivo será tanto maior quanto maior o conteúdo de justiça da disposição derrogada (WOLFGANG WURMNEST, § 307, cit., nm. 66). Trata-se de uma distinção controversa, considerada pouco transparente pela doutrina e que por isso tem por esta sido tentativamente densificada - veja-se já a doutrina alinhada em JAN SCHAPP, "Die Leitbildsfunktion...", cit.,, p. 622. Parece-nos, porém, constituir uma coordenada útil, num juízo que, sendo de ponderação, não deverá ter-se por monolítico. Pouco probante nos parece, pois, a proposta de Schapp, que, considerando - bem - que o Direito dispositivo vigente a cada momento não pode levar à paralisia da evolução das práticas negociais, defende que apenas pode valer como parâmetro de controlo dos clausulados o Direito que possa ainda ter pretensões de vigência face ao carácter massificado das práticas negociais sob escrutínio, e não aquele a que subjaza o paradigma da contratação individualizada (pp. 624-625). Sem refutar a valia de uma interpretação teleológica das normas disponíveis, tomando em conta a sua pertinência face ao
} 
Por último, relevam claramente, à face do nosso ordenamento, nos termos do art. $16^{\circ}$, as circunstâncias específicas da contratação, atinentes à protecção de expectativas, agora num plano concreto, decorrente do teor das cláusulas inseridas no texto contratual, bem como de outras circunstâncias ligadas à contratação ${ }^{48}$.

Vemos agora a protecção de expectativas a operar num plano concreto, e não já objectivizado, o que torna patente o polimorfismo do comando da transparência na utilização de cláusulas contratuais gerais. Na verdade, quando "uma cláusula restringe ou suprime um efeito do contrato cuja produção o aderente pode legitimamente esperar, por corresponder à imagem comum do tipo contratual em causa" ${ }^{49}$, tanto pode bastar a tutela no plano do conhecimento, assegurando a representação do desvio do contrato face às utilidades contratuais normalmente esperadas, como essa tutela não ser já bastante. Se, no primeiro caso, estamos ainda no plano da tutela de inclusão, no segundo estamos já em sede de tutela de conteúdo, vedando terminantemente a produção de efeitos pela cláusula que contrarie aquelas expectativas ${ }^{50}{ }^{51}$. À face da sistemática por que optou o legislador do RJCS, o controlo da

dito carácter massificado da contratação, parece-nos, por um lado, como resultou do exemplo dado em texto, que não deverá ser esse o único factor tido em conta na apreciação; e, por outro, que a conclusão pela dita pretensão de vigor do Direito supletivo face ao carácter massificado do negócio implicará possivelmente a transferência para um momento prévio do juízo de outros vectores atendíveis.

${ }^{48}$ Esta também se coloca a propósito dos contratos de seguro, não sendo de aceitar uma perspectiva como a de JÜRGEN PRÖLSS, $I$. Rechtsgrundlagen des Versicherungsvertrages, cit., $\mathrm{nm}$. 79-85, que considera que o prejuízo desproporcional que, já em todo o espectro da apreciação de ccg, deve ser considerado de um ponto de vista generalizador, deve sê-lo decisivamente à face do contrato de seguro. Aqui, não seria portanto de atender às circunstâncias concretas da contratação. $O$ autor faz desta sorte entrar - em linha de resto com a primazia que dá aos elementos técnicos na construção dogmática do contrato - a consideração dos interesses da comunidade de segurados, considerando que a limitação desadequada da cobertura só começa quando puser em causa as necessidades de um número preponderante de segurados. Com o argumento da defesa dos interesses da comunidade de segurados derrotar-se-ia o que resultaria da interpretação do Direito alemão à luz da Directiva; de resto, o autor considera que o segurado não ficaria aqui desprotegido, sendo tutelado no tocante às suas circunstâncias particulares em sede de inclusão das cláusulas no contrato. Porém, face aos argumentos legais, o autor parece afinal admitir que o controlo deva atender às circunstâncias concretas, se bem que limitadamente. Assim, apenas se deveria atender às circunstâncias concretas quando estas, mesmo numa análise tipificada, estivessem já na margem da desadequação, espelhando uma situação concreta de inferioridade do contratante. Quanto às necessidades especiais do segurado, só relevariam exactamente as que estivessem já para lá das fronteiras da "normalidade" e que se tivessem tornado aparentes no processo da conclusão do contrato, sendo reconhecíveis para o segurador. Poderiam de todo o modo ser feitas valer circunstâncias específicas da contratação mesmo quando desfavorecessem no caso o aderente face ao que seria o juízo resultante da análise tipificada - assim, quanto a ambos os aspectos, JOSÉ CARLOS MoITINHO DE ALMEIDA, "Cláusulas...", cit., pp. 92-93, salientando argumentos literais da Directiva para defesa do segundo. Face à especificidade que Prölss quer aqui conferir aos seguros, privando o segurado de protecção quanto à confiança concretamente gerada no processo da contratação, não vemos porque se há-de dar ao segurador essa possibilidade, libertando-o da especial diligência na formulação das cláusulas e contratação que a sua assinalável vantagem informativa nesta sede lhe confere (discordando também de Prölss, JOSÉ CARLOS MoITINHO DE ALMEIDA, "Cláusulas...", cit., pp. 92-93).

49 JOAQUIM DE SOUSA RIBEIRO, ""Economia...", cit., pp. 975-976.

${ }^{50}$ A jurisprudência germânica tem tornado o controlo da transparência transversal a essas várias fases, colocando-a tanto no plano do controlo do conhecimento da generalidade do clausulado, como, ainda em sede de controlo da inclusão, na fiscalização do carácter surpreendente de uma cláusula particular, como ainda - e agora com distância face aos dados legais nacionais - em sede do próprio controlo do conteúdo; ao ponto de se verberar a perda de foco da invocação da transparência, "fórmula vazia" que acolheria puro casuísmo jurisprudencial (JÜRGEN BASEDOW, "Transparenz...", cit.,, pp. 1045-1046; ALEXANDER BRUNS, § 307, cit., nm. 99, reportando-se criticamente à força expansiva do parâmetro). Tal força expansiva da apreciação da transparência no ordenamento alemão é mais bem compreendida quando relembrada aqueloutra diferença face ao nosso ordenamento: a proibição de controlo de abusividade das cláusulas que configurem as prestações principais do contrato, que, vista à luz da Directiva, apenas recua quando tais cláusulas não sejam claras e compreensiveis. Foi esta última a porta de entrada para a apreciação do conteúdo das cláusulas que recortam as prestações principais, tendo aí grande relevância a jurisprudência bancária, especialmente a atinente às cláusulas de determinação dos juros no mútuo com hipoteca e a relativa às cláusulas de data-valor das operações - sobre a sua evolução, JOHANNES KÖNDGEN, "Grund...", cit.,, pp. 944-946. O controlo efectuado foi, porém, um genuíno controlo da falta de equivalência entre as prestações (JÜRGEN BASEDOW, "Transparenz...", cit.,, pp. 1049-1050, e jurisprudência analisada).

${ }^{51}$ Assinale-se que o critério da transparência se tornou entretanto o eixo central do controlo dos clausulados no ordenamento jurídico francês, à luz do controlo das cláusulas de exclusão de riscos. O parâmetro é o da protecção das expectativas do segurado, impondo que lhe sejam compreensíveis as condições nas quais está ou não está garantido. A listagem de cláusulas de exclusão invalidadas pela jurisprudência superior francesa é elucidativa quanto ao carácter massivo da intervenção nos clausulados que se processa à sua sombra (Groutel in HuBERT Groutel, FABrice Leduc, PHILIPPE PierRe, et al., Traité... cit., pp. 263 e ss.). Trata-se aqui tanto cláusulas gerais e conceitos indeterminados, de índole, portanto, jurídica, que se considera que o segurado não está em condições de precisar - como, no acórdão, de 8 
transparência, enquanto controlo atinente ao carácter surpreendente da cláusula, concerniria a aspectos meramente formais, nos termos do art. $8 .^{\circ}$, c) do RJCCG. Os demais artigos que procedem à tutela da inclusão dão, porém, cobertura generalizada às hipóteses em que a falta de possibilidade por parte do segurado-aderente de tomar conhecimento do conteúdo do contrato provém do facto de a cláusula contrariar as expectativas concretamente formadas no processo negocial, tendo em atenção o concreto segurado e o risco de que se $\operatorname{trata}^{52}$. Resta

de Outubro de 1974, que marca o início desta jurisprudência, a "inobservância indesculpável das leges artis - , como de noções práticas tidas por muito abertas - "doenças ou acidentes ocasionados pelo alcoolismo", "doenças sexualmente transmissíveis", face a seguros de acidentes ou doenças, "valores", ou o "deixar as chaves em qualquer lugar facilmente acessível do exterior", face ao seguro contra roubo ou furto - ou deveres de conduta recortados de um modo vago - a exigência de que o segurado "zele como bom pai de família pela preservação e segurança do imóvel", ou "adopte todas as precauções habituais e razoáveis para a segurança e conservação dos bens segurados"; a exclusão dos "danos resultantes da falta de reparações indispensáveis que incumbam ao segurado" - ; ou ainda enumerações enunciativas de circunstâncias não cobertas - "... ou outro problema lombar", "...ou outros fenómenos naturais de carácter catastrófico"; como mesmo cláusulas que façam referência a regulação legal ou profissional de um modo tido como muito geral - como é o caso da cláusula que determina que o segurador poderá recusar a garantia em caso de uso de materiais de construção não convencionais, não conformes aos regulamentos em vigor; ou da cláusula do seguro de responsabilidade do promotor que exclua as consequências de operações deliberadamente levadas a cabo em infraç̧ão aos textos regulamentares aplicáveis a operações de construção.

${ }^{52}$ Usando os exemplos fornecidos por JÜRGEN BASEDOW, "Transparenz...", cit.,, p. 1047, pense-se no caso do segurador que anuncia uma linha disponível 24 horas para apoio em caso de sinistro, que poderá suscitar confiança na suficiência desse contacto para a comunicação do sinistro. A nossa jurisprudência tem, em sede seguradora, usado em considerável medida o controlo de inclusão para cassar cláusulas falhas de transparência do clausulado. No entanto, mesmo aí se ocultam na verdade duas abordagens diversas. De um lado, encontra-se a fiscalização assente na relação jurídica em causa, sendo o eixo colocado nas possibilidades de conhecimento da cláusula pela contraparte concreta do segurador. Sirva de exemplo o ac. do STJ de 26 de Novembro de 2002, Processo n. ${ }^{\circ} 02$ A3560. Estava em causa a interpretação da cláusula de recorte primário do risco seguro que determinava o alcance da cobertura de danos causados por tempestade. No caso, o telhado dos segurados havia desabado em consequência de acumulação de neve causada por tempestade de neve, o que extravasa a definição contratual de tempestade. Não obstante, o TRC e, na sua senda, o STJ, vieram considerar que, de acordo com o horizonte de um declaratário normal colocado na posição dos reais declaratários - residentes na Guarda, onde os nevões eram frequentes e o termo "tempestade" abarcava geralmente o sentido da tempestade de neve -, o termo em causa designaria também tempestades de neve. Como tal, apartando-se do comum uso do termo, a cláusula deveria ter sido comunicada de modo a permitir o conhecimento efectivo do seu conteúdo; não tendo tal ocorrido, deveria ter-se por expurgada (art. 8..$^{\circ}$ a). Aqui, estamos perante o juízo individualizado típico da tutela de inclusão, sendo a falta de transparência aferida -e, como tal, havida por solucionável - à luz das possibilidades de conhecimento da cláusula em concreto. Nesta sede, se se pondera ainda a contrariedade à boa fé por defraudamento de uma confiança legitimamente fundada face ao escopo contratual em causa, finca-se o juízo nas representações que seriam razoavelmente formadas pelo concreto destinatário. No que, note-se, vai patenteada a pertinência da aplicação cumulativa dos dois parâmetros ínsitos no art. $16^{\circ}$, nada impondo que esta ocorra de modo separado (aludindo a uma confiança face ao objectivo negocial, JOAQUIM DE SOUSA RIBEIRO, O problema... cit., p. 412). Noutras hipóteses, o tribunal finca-se claramente na falta de transparência construída em moldes tipificados: contrária às expectativas do segurado será uma cláusula de "carácter anómalo, atento o tipo de contrato e os interesses que lhe subjazem". Ao modo alemão, o carácter surpreendente da cláusula é referido também a circunstâncias inerentes não a uma confiança concretamente suscitada, mas sim à discrepância entre o sentido esperado face ao tipo de contrato em causa e o clausulado. Ora, aqui já estaríamos na verdade a operar em sede de tutela de conteúdo, aferindo do carácter abusivo da cláusula. Sirva agora de exemplo o ac. do TRP de 27 de Fevereiro de 2014, Processo n. ${ }^{\circ}$ 2334/10.7TBGDM.P1, pontos 3.1. e 3.3. Tratou-se aqui também de fundamentar a invalidade das - por várias vias verberadas e rejeitadas - cláusulas que definem a invalidez absoluta e definitiva de modo cumulativo como estado que se instala "quando, em consequência de doença susceptível de constatação médica objectiva, [a pessoa segura] fique total ou definitivamente incapacitada de exercer qualquer profissão e necessite de recorrer, de modo contínuo, à assistência de uma terceira pessoa para efectuar os actos normais da vida diária" (realçados nossos). A argumentação mais comum para fundar a expurgação deste tipo de cláusula é, porém, geralmente, fundada na tutela de validade, e não de inclusão. O TRP considerou que se trata aqui de uma cláusula-surpresa dado o seu "carácter anómalo, atento o tipo de contrato e os interesses que lhe subjazem", bem como o facto de figurar em local pouco explícito do mesmo contrato. Interpreta-se o art. 8. ${ }^{\circ}$, al. c), do RJCCG, de modo diverso ao que vem indiciado pelas referências da dita alínea apenas a aspectos da apresentação externa do contrato. Quanto ao "carácter anómalo [da cláusula], atento o tipo de contrato e os interesses que lhe subjazem", o acórdão considera que o alcance normal da invalidez não implica a sobredita necessidade de recorrer, de modo contínuo, à assistência de uma terceira pessoa para efectuar os actos normais da vida diária. O sentido desta cláusula não pode deixar de ser considerado à face do sentido do contrato em que se insere, que é o de reforçar a garantia de pagamento: se se pretende garantir o credor, então o sentido de invalidez que se compatibiliza com tal escopo é o da que impede o segurado de exercer uma profissão e auferir rendimento. Com bem salienta o aresto do TRP, o facto de o segurado necessitar ainda de auxílio para a prática do cuidado quotidiano da sua pessoa é totalmente irrelevante do ponto de vista do credor. O aresto não chega a aferir da validade material da cláusula, já que considera que esta sucumbe logo em sede prévia, não chegando sequer a integrar o contrato. Considerando-se aí, porém, que essa segunda parte da cláusula não é mais "do que um artifício pelo qual a seguradora, predisponente da cláusula, intenta sub-reptícia e encapotadamente restringir o alcance da cobertura do seguro", possivelmente viria esta a ser considerada incompatível com a boa fé contratual. Discorre-se, porém, em sede prévia: defende-se aí que a ordem jurídica portuguesa não pode deixar de atender, no âmbito do controlo da transparência atinente ao carácter surpreendente das cláusulas, e tal como a ordem jurídica alemã, ao conteúdo do contrato, e não apenas ao seu aspecto externo. Não poderia deixar de ser assim, porque as discrepâncias entre o sentido geral do contrato e o de uma cláusula que se mostrasse face a ele anómala não seriam menos aptas a impedir a cognoscibilidade das ditas cláusulas do que questões atinentes ao aspecto externo do clausulado. Como tal, não poderia nuns casos dar-se a cláusula como integrante do contrato e noutros dá-la à partida por não integrada, quando em ambos estivesse em causa a não percepção das cláusulas em questão. Seria, segundo o aresto, incoerente apodar de meramente conteudístico um vício que advinha exactamente dos obstáculos colocados pelo sentido da cláusula à possibilidade da sua percepção: tal equivaleria a dar a cláusula como integrante do contrato para afinal lhe negar validade por não estar em condições de ser percebida. Critica-se, assim, o pensamento de Sousa Ribeiro, quando o autor reduz o controlo do carácter surpreendente da cláusula, conforme o art. $8 .^{\circ}$, al. c), do RJCCG, apenas à apreciação do seu aspecto externo. No caso, além do

Revista Thesis Juris - RTJ, São Paulo, v. 9, n. 2, p. 415-432, jul./dez. 2020 
porém saber se, num sistema como o nosso que não tem que se haver com limites formais prévios quanto ao reduto sobre o qual incide o controlo de conteúdo - sendo tais limites teleologicamente traçados pela doutrina e jurisprudência -, há ganhos em dar ao parâmetro da transparência um papel autónomo em sede de controlo de conteúdo.

Pensada a falta de transparência enquanto frustração das expectativas objectivas que legitimamente se colocam face ao tipo contratual ou ao concreto contrato ${ }^{53}$, dir-se-ia que não vem aí substituir-se ao controlo da equivalência, que dá verdadeiramente o conteúdo ao juízo. Já pensada a falta de transparência enquanto indiscernibilidade, para o aderente, do conteúdo dos direitos e deveres contratuais, aparta-se o seu juízo mais decisivamente do controlo central da equivalência. E não se esgota, também, no controlo em sede de inclusão - pode ter sido cumprido o ónus de levar o clausulado ao conhecimento do aderente, mas, dada a própria indeterminação do conteúdo das cláusulas, não ser possível extrair destas, a priori, a totalidade dos seus efeitos prospectivos. Trata-se de uma questão especialmente apta a levantarse em sede de contratos duradouros, onde o uso de cláusulas de Tatbestand aberto surge como válvula de ajustamento do contrato às alterações na realidade subjacente.

Ora, em sede de controlo de conteúdo, este juízo de falta de transparência poderá revelar utilidade na concretização de atentados à equivalência entre as atribuições, já que a falta de transparência encapota ou permite essa mesma falta de equivalência. Num caso extremo, é isso que ocorre quando o conteúdo da cláusula em apreço se tornar, para o aderente, indeterminável ao ponto de a cláusula atribuir ao predisponente total discricionariedade na conformação futura dos direitos e deveres do cliente ${ }^{54}$. Em termos mais gerais, a falta de

aspecto material atinente ao dito carácter anómalo da cláusula face ao sentido do contrato, o seu carácter surpreendente era ainda fundado nas questões formais de esta ser parte de uma disposição incluída em local secundário do contrato, como cláusula complementar, entre as condições especiais da apólice. Trata-se, como começámos por dizer, de um critério com virtualidade explicativa das situações de contradição entre o sentido da regulação padronizada e o teor da cláusula: pensadas as expectativas do aderente de modo objectivo, face ao tipo, pode dizer-se que estas são num juízo abstracto defraudadas em situação de desequilíbrio. Porém, levar este género de controlo, abstracto e tipificado, para o momento da tutela da inclusão, é pôr tal tutela em condições de engolir a tutela conteudística - que é a que dispõe dos instrumentos metódicos necessários a operar a aferição e causa.

${ }^{53}$ Vimos na nota anterior exemplos do juízo de frustração de expectativas face às concretas circunstâncias da contratação (considerado o horizonte interpretativo de um declaratário normal colocado na posição do real declaratário, atenta a sua geografia), bem como face ao sentido e fim do tipo contratual, visto o risco a cuja cobertura se procede. Resta acrescentar a estas hipóteses aquelas, muito debatidas na doutrina alemã, relativas aos casos em que uma cláusula ancilar ou lateral vem "modificar substancialmente a relação de valor entre ambas" as atribuições contratuais, contrariando já não uma norma de direito objectivo, mas "a conformação autonomamente fixada pelo utilizador para o núcleo essencial do contrato" (JOAQuim DE SOUSA RiBEIRO, O problema... cit., pp. 407 e ss.). Também aqui é tanto a confiança colocada em dado conteúdo contratual, como a finalidade visada com o contrato, que são postas em causa. Note-se que, nestas hipóteses, vindo a frustração de expectativas de aspectos atinentes à sistemática contratual, encontramo-nos em terreno parcialmente coincidente com o da tutela em sede de inclusão. Um exemplo de casos com este recorte em sede seguradora decorre do ac. do STJ de 2 de Junho de 2015 , Processo n. ${ }^{\circ}$ 109/13.0TBMLD.P1.S1, em que se considerou, perante o risco de invalidez, que a cláusula que excluía a cobertura em caso de doença psiquiátrica, encontrando-se prevista entre um bloco de cláusulas de exclusão atinentes a condutas da pessoa segura ou a eventos anormais, deveria ser tida como cláusula-surpresa, por passar facilmente despercebida a um sujeito colocado na posição do aderente.

${ }^{54}$ Cfr., na nossa jurisprudência, o ac. do STJ de 24 de Abril de 2014, Processo n. ${ }^{\circ}$ 6659/09.6TVLSB.L1.S1, que considerou que a cláusula que fazia depender o reconhecimento da situação de invalidez total e permanente da sua confirmação por um médico da seguradora, para além da sua certificação perante junta médica, favorece excessiva e desproporcionadamente a posição da Seguradora, predisponente, já que não havia razão compreensível para essa exigência, e que além disso se punha a final a decisão sobre efectuar ou não a prestação nas mãos do segurador, que seria "juiz em causa própria". Em geral, cfr. JÜRGEN BASEDOw, "Transparenz...", cit.,, pp. 1050-1051, 1054. O autor considera, em sede de controlo de conteúdo, que o parâmetro é o da equivalência entre as prestações. De resto, é inevitável a incompletude contratual em relações duradouras, podendo sempre apodar-se de intransparentes cláusulas de contratos duradouros, como os de seguros, que se determinam sucessivamente por circunstâncias futuras - vg., a exigência de cumprir regulamentos depende dos que valerem a cada 
transparência mostra ainda aptidão a colidir com a preservação do sentido e fim do contrato, não permitindo ao aderente determinar as utilidades que dele retira. Trata-se de incidência que colhe a maior importância no contrato de seguro.

Com efeito, o escopo do contrato de seguro prende-se com a transferência de um risco em termos materiais, de modo a permitir ao sujeito saber que terá os meios necessários a afrontar consequências desfavoráveis que um evento futuro é apto a produzir na sua esfera. Esta vertente prospectiva da transferência do risco é decisiva: o contrato não deixa de cumprir a sua finalidade ainda que o sinistro não venha a ocorrer. O contrato visa, sim, à garantia da imunização da sua esfera face a eventuais consequências desfavoráveis de eventos incertos visa, portanto, à segurança, ou, se se quiser, à possibilidade de planificação económica dos sujeitos. Ora, esta possibilidade impõe especiais garantias de certeza quanto ao alcance da cobertura adquirida, sob pena de a "aquisição de segurança" intendida se ver esvaziada. É aqui que o comando da transparência surge no papel de guarda avançada do cumprimento da finalidade do contrato, sendo indispensável a tal aquisição de segurança a cognoscibilidade da extensão da cobertura oferecida. Tal não passa, porém, sem ponderação com as exigências justificáveis de consagração de cláusulas gerais e conceitos indeterminados nos clausuladosnão só porque sem estes não é sequer possível a delimitação do risco ou a adaptação de um contrato muitas vezes duradouro à realidade subjacente; mas porque, na sua interpretação, o segurado sempre beneficiará da tutela da interpretação mais favorável ao aderente ${ }^{55}$.

Para lá deste parâmetro geral, na concretização do sentido e finalidade dos contratos de seguro, tem uma particular força reitora a ideia de que se trata da preservação da distribuição de riscos própria do contrato. Esta deve ser perspectivada, como dissemos acima, face à concreta manifestação do tipo posta em marcha - face ao concreto risco a cuja cobertura se pretendeu proceder ${ }^{56}{ }^{57}{ }^{58}$. Tratando-se aqui da concretização de um juízo de

momento. Aqui, urge precisar o que se entende por transparência e falta dela. Segundo o autor, apenas teremos uma ofensa relevante à transparência quando a cláusula atribuir ao predisponente total discricionariedade na conformação futura dos direitos e deveres do cliente (pp. 1051, 1054).

${ }^{55}$ MANFRED WANDT, "VVG $§ 28$ Verletzung einer vertraglichen Obliegenheit", MüKo VVG, I, THEO LANGHEID, MANFRED WANDT (org.), C. H. Beck, Munique, 2010, disponível em http://beck-online.beck.de (25.02.2012), nm. 30.

${ }^{56}$ AleXANDER BRUNS, $\$ 307$, cit., nm. 115.

${ }^{57} \mathrm{O}$ art. $45 .^{\circ}$, n. ${ }^{\circ}$ 1, RJCS, na linha do que resultava já do art. 9. ${ }^{\circ}$ do RJT (tido por imperativo - PEDRO ROMANO MARTíneZ, "Cláusulas contratuais gerais e cláusulas de limitação ou de exclusão da responsabilidade no contrato de seguro", Sc. Iur. 306 (2006), p. 253), determina que as condições gerais e particulares do contrato de seguro não podem modificar a natureza dos riscos cobertos, tendo em conta o tipo de contrato de seguro celebrado. Ao abrigo do art. 13. ${ }^{\circ}$, n..$^{\circ}$, trata-se de norma semi-imperativa - o que, dentro dos limites colocados pelas normas de supervisão, é compatível com uma possibilidade de conformação transparente da cobertura. Esta norma não exprime, porém, tudo o que dizemos em texto: na preservação da distribuição dos riscos própria do contrato, vai compreendido mais do que a hipótese extrema em que o contrato passa a cobrir outro risco - vão nela também compreendidas as hipóteses em que se altera o quantum do risco coberto, sem que a sua qualidade se altere.

${ }^{58}$ Não nos parece aqui probante apelar ao art. $21^{\circ}$, e), do RJCCG, que tem por absolutamente proibidas as cláusulas que alterem a distribuição do risco contratual. Trata-se, conforme nos dá conta ANA PRATA, Contratos de adesão e cláusulas contratuais gerais, Almedina, Coimbra, 2010, p. 493, de norma de inspiração francesa, mas que é actualmente uma originalidade no Direito comparado mais próximo. Trata-se de norma que carece de uma interpretação cuidada, sob pena de, por força da polissemia do conceito de risco no Direito, tragar grande parte dos clausulados - como assinalámos já, toda a criação de deveres laterais no contrato gera uma redistribuição de riscos contratuais. Acresce que, estando inserida no elenco das cláusulas absolutamente proibidas, esta seria avessa a uma ponderação no plano do quadro negocial 
proporcionalidade, a análise é gradativa: quanto mais a cláusula em questão comprimir a cobertura do risco pactuado, à luz da medida de tal cobertura necessária ao efeito útil da cobertura, mais a cláusula é suspeita de colocar em perigo a finalidade do contrato - não sendo de resto necessário que inviabilize totalmente esta finalidade, mas só que a coloque em risco, para que mereça censura.

Na matéria do controlo da legitimidade das cláusulas de delimitação do risco no contrato de seguro, a jurisprudência nacional tem, aliás, sido pródiga na mobilização destes parâmetros. É, por exemplo, à sua luz que têm sido invalidadas as cláusulas dos seguros contratados para garantia de crédito que cubram riscos de invalidez, quando o preenchimento dos pressupostos da invalidez requeira a impossibilidade de subsistência funcional sem o apoio de terceira pessoa. Considera-se tal descrição demasiado restritiva face ao escopo do contrato, que é o da cobertura do risco de ficar economicamente impossibilitado de solver o contrato de mútuo, e, retira-se daí a consequência da sua nulidade ${ }^{59}$. Já não seria assim, claro está, se se tratasse exactamente de um seguro de dependência.

Numa última nota, diga-se que, curando-se aqui de mobilizar o parâmetro geral de controlo do carácter abusivo da cláusula, o juízo vale quer o aderente seja um consumidor, quer actue como profissional. Não obstante, tal aferição deverá ser modulada em atenção à maior capacidade de que disponha o aderente empresarial, em atenção ao círculo negocial a que pertença ${ }^{60}$. Diferentes círculos negociais têm diferentes interesses e necessidades de protecção, que podem compensar um maior afastamento em relação ao modelo legal, desde que assegurada a devida transparência do clausulado.

Lembre-se, por fim, que, mesmo entre os seguros de grandes riscos, onde a generalidade das normas do RJCS tem carácter supletivo, estas não perdem o seu papel de referente - a sua supletividade seria, como visto, relativizada pelos riscos envolvidos pela contratação com recurso a ccg ${ }^{61}$.

padronizado, sendo alvo de um desvalor abstractamente pressuposto pelo legislador (ANTÓNIO PINTO MONTEIRO, Cláusulas limitativas e de exclusão da responsabilidade civil, Almedina, Coimbra, 2003, p. 386-f; AlmENo DE SÁ, "Lei... ", cit., pp. 38-39). Não é, pois, este o parâmetro para demarcar os limites à possibilidade de conformação do risco tomado pelo segurador através da criação de exigências de conduta, em face da manifestação do contrato de seguro em causa.

${ }^{59}$ Trata-se, recorde-se, por exemplo, do ac. do STJ de 7 de Outubro de 2010, Processo n. ${ }^{\circ}$ 1583/06.7TBPRD.L1.S1; ac. do STJ de 27 de Maio de 2010, Processo n. ${ }^{\circ}$ 976/06.4TBOAZ.P1.S1 (sumário); mais recentemente, ac do TRL de 26 de Fevereiro de 2013 , Processo n. ${ }^{\circ}$ 411/10.3TBTVD.L1-7.

${ }^{60}$ MANFred WOLF, "BGB $\S 307$ Inhaltskontrolle", in AGB-Recht Kommentar, MANFred Wolf, WALTER F. LiNDACHER, THOMAS PFEIFFER (org.), C. H. Beck, Munique, 2009, pp. 316-318.

${ }^{61}$ HARRY SCHMIDT, "Allgemeine Versicherungsbedingungen", in AGB Recht Kommentar, PETER UlmER, HANS E. BRANDNER, HorstDiETHER HENSEN (org.), Dr. Otto Schmidt, Colónia, 2011, p. 1774, salientando que as normas semi-imperativas da VVG fornecem o padrão de apreciação também para grandes riscos. 